sort liad active pulmonary tubcrculosis. The ehief eomplaint of the patients was pmin (74.5 per eent.), usually situated in the lower abdoinen. Not much informution was obtained from the inenstrual history, although it was noted that 62 per cent. of the patients had dysmenorrliea and 41.5 per eent. menorrhagin. Amenorrhen ocelirred in only 6.5 per cent. of the patients. Nearly half of the patients lad clysuria, nocturia and pollakiuria and more than half of the patients were eonstipated: Approximately one-fourth of the patients attributed the onset of their trouble to some uterine activity (menstruation, pregnaney, cte.). Half of the patients had lost weight during their illness but the physieal examination presented no characteristic findings, cxeept that one-fourth of the patients had pulmonary tuberculosis. Prc-operative elevation of temperature was reeorded in 62.5 per eent. The blood usually showed either an absolute or a relative lenkopenia nnd a reduced hemoglobin. The eorrect diagnosis beforc operation was made in only 13 per cent. of the cases, and in morc thinn half of thesc the diagnosis wus aided by the presence of aseites. In 53 per cent. of the cascs it wus necessary to perform a radical operation and complieations during the operation occurred in 14.5 per cent. of the patients. One liundred and four eases were drained and of these 17.3 per cent. developed fecal fistulie. In onc-third of all the patients there was suppuration of the aldominal ineision. In 99 per eent. of the cases both tubes were involved, in 68 per cent. the peritoncum was involved and in 3 per ccnt. the uppendix was tuberculous. Thic operative mortality in this series was 7.6 per eent., but the prognosis is grave in the prescnce of tuberculosis elscwhere in the body, where fever exists and where the peritoneum is involved. By means of follow-up letters 00 patients were traced and of this number 78 wcre found to be living froin two montls to thirty years after the operations and nenrly all of those who are alive are in good condition.

Gynecologic Significance of Appendicitis in Early Life.-It seems to be well estnblished that the appendix may undergo eonsiclerable grades of inflnumation and yet eventually be restored to a eondition of approximatc normality. It is entirely probable that during the inflammatory pcriods of a chronic appendieitis, a serons or serofibrinons exudate is prodneed which finds its way by gravity into the true pelvis sinee one often encounters such an exudate in apparently: uneomplieated pelves and wonders whence it eame. Therefore, Graves (Arch. Surg., 1921, ii, 315) believes that it is quite reasonable to suppose that, although this exudate is usually absorbed by the peritoneum, under certain conditions it may be sufficient either through baeterial or chcmieal influence to destroy the supcrficial epithelium of the pelvie peritoneum and to stimulate the subserous conneetive tissue into the formation of organized plastic adhesions; or it may itsclf becomc organized and form the basis of adhesions. In this way may be explained theoretically the cases not infrequently encountered in which, without sign or history of gonorrhea or puerperal sepsis, adhesions are found in the posterior cul-de-sac or implieating the surfaces of the adnexa while the appendix shours only mild cvidence of disease, or perhaps none at all, to gross appearance. If besides the pelvie adhesions there is added a well-defined chronic appendicitis, or the scar of an 
nppendix operation performed in youth, the author believes his explanation is still more plausible; eertainly more so than the attempt to ascribe the condition to an entirely improbable gonorrheal infeetion. For this reason appendieitis in elildhood or young girlhood is an aflection whieh must be regarded not simply with referenee to the diseased organ itself but to the serious harm which it may excrt on the pelvie organs, if left to work out its own destiny in a state of ehronic inflammation. Early operation is therefore indieated in ehildren when there is any suspiejous evidence of appendieular infection. In the acute stage the appendix slould be removed immediately to forestall if possible a seeondary involvement of the adnexa. If pus is present, every eftort shoult be made to drain the pelvis, it being fensible in certain cases to drain the pouelt of Douglas through the vagina. Execpting in eases of loealizecl abscess it is advisable to make a median line incision in order tlat the pelvie organs may be inspected, and that any abnormalities of position or plastic adherence may be remedied by n proper surgical procedure.

\section{HYGIENE AND PUBLIC HEALTH}

onoER tiE chamoE or

MILTON J. ROSENAU, M.D.,

PROFESROR OF PREVENTIVE MEDICINE AND BTOIENE, HATVARD MEOICAL BCHOOL, BOBTON, ACABSACUDOETTB,

AND

GEORGE W. McCOY, M.D.,

DIRECTON OF HYOLENC LABORTORY, DNTTED BTATES POBLTC HEALTH gERVICE, WABMINOTON, D. e.

Studies in the Treatment of Mialaria.-Marise and Moss (Public Ilealth Reports, 1920, xxxv, 3082) review certain experimental observations on the use of quinin nnd other remedies in the trentment of mnlaria. The frequeney of relapse under quinin is emphasized, even though large doses are given; for example, 45 grains daily for from three to eight weeks nnd smaller doses lead to high pereentnges of relapse. The maximum tolerated dose is 120 grains of quinin sulphate on each of two consecutive days. Neoarsphenamine in doses of 0.45 to 0.9 grnm eontrol the febrile paroxysms but do not eure, but this drug, in eombination witl quinin, is more effective in simple tertian infections than is either drug alone.

Syphilis as a Cause of Insanity.-Donaldson (Public llealth Reports, 1921, xxxvi, 67) by means of a questionnaire, ascertained the following finets with respect to state institutions for the insmne: Percentage of male inmates whose insanity is due to syphilis, 6.2. Pereentage of fenale inmates whose insanity is due to syphilis, 2.2. Pereentage of inmates (nale and female) whose insanity is due to syphilis, 3.9. Percentage of male admissions whose insanity is due to syphilis, 
15.5. Pereentage of femalc admissions whose insanity is due to syphilis, 6.1. Percentage of admissions (male and femnles) whose insanity is due to syplitis, 10.4. 'The mueh larger figures for admissions over inmates are due to tlie sloort period of survival-of cases adinitted for syphilitie mental disorders.

Venereal Disease Incidence at Difierent Ages.-King and Srdenstmcken (Public Ilealth Reports, 1920, xxxv, 3091) summarizc their studies as follows: (1) For the purpose of throwing some light upon the question of the age incidence of venereal infections, and in the absence of complete data for any definitcly and accuratcly observed populution group, certain tabulations were made of approximately $\$ 400$ case reports of venereal disenses among white persons in Indiana.

(2) Considcring tlese cases as fair samples of the total cases of that type whieh actually exist in the population under eonsideration, indices of venerenl disense ineidence aecording to age of onset were coinputed for persons of both sexes and of different marital eondition by adjusting tlie age distribution of cases to that for the population of Indiana in 1910. (3) While the data cannot be considered eonelusive, they suggest the following points: (a) 'I'le greatest incidence of venereal infections ocenrs in early adult ages, between seventecu and twenty-five. This is true of botli unales and females. (b) The ineidence of venereal infections is eurlier annoug feumales than males. The molal or penk age for females is nineteen yeurs, whilc that for males is npproximately twentyone years. (c) While the data are not definite on this point, the evidenee suggests thut among persons married at the time of report, venereal infections were largely premurital in the ease of mules and postmuritul in the cesse of feunales. (d) There is a wide divergenee in the incidence curves for males who were married previous to the time of report and for males who lud remained single. In the one case, infections were confined eliefly to the younger adult ages (under twenty); in the other, the incidence in the adult ages (twenty to twenty-four) wis considerably lighler than in tlsc younger uges. 'The effeet of inarriuge apparently was to greatly lessen the ineidenec of venereal infection among males. (c) Gonorrliea apparently oceurs ut slightly younger ages than syphilis or clianeroid nmong both mnles und females. (4) In vicw of the limitations of the data with respeet to the number of cases reported, the stage at which discase was reported, the possible errors in determining accurately the nge at which infection occurred, and the use of the 1910 age distribution of populition, these observiltions eannot, of course, be regarded as definitely conelusive.

Studies on the Lothal Action of Some Meningococci on Mice, with Special Reference to the Protective Properties of Antimeningococcic Serum.-Neile and TaFt (IIygienic Laboralory Bullotin, November, 1920, p. 93) endeavored to determine the value of protection tests as is inethod of estimating the therapeutic value of antimeningoeoccie serum. It was found that dead meningococei were about as fatal for mice as werc living ones, though large doses were required in either ease. The method docs not show relative value execpt when praetically the difference is very great. The irregular results do not lend encouragement to the use of the metlod for practical purposes. 
Report on Investigation of Tsphoid Fever Epidemic at Greenville, Tenn.-Hamnun (Public.Heallh Reports, 1921, xsxvi, 72), a Sanitary Enginecr, reports an outbrenk of 61 eases with scren deatlis clue to contaminated spring water used as a municipal supply. 'Tlic supply was treated with hypochlorite but the disinfectant was not properly employed, and analysis of the water showed it to be of a poor sanitary quality.

The Tropin Reactions of Antimeningococcus Serum.-Evans, (IIygienic Laboratory Bulletin, November, 1920, p. 43) gives the following summary of the work reported: The plagocytic test for bacteriotropins is a workable test which distinguishes clcarly between a normal scrum and a serum containing the specific antibodies. The important phagocytic antibodies in meningococcus scrum are bacteriotropins. That is, they are not dependent upon complement for their activity. A ligh concentration of tropins docs not inhibit phagocytic action, but there is in scrum a poisonous ssbstance active against lcukocytes of a forcign spccies, which suppresses phagocytic activity in low dilutions of the scrum. No stains of meningococci werc found which resisted phagocytosis after treatment with scrum containing the specific tropins. All strains of meningococci tested produced tropins in inoculated rabbits. But not every inoculated rabbit produced tropins, presumably because of individual differenees in the animals. Some strains regularly produced tropins in higher titer than other strains. After long artificial cultivation meningococci inay lose their tropinogenic power, and their power to respond to active tropins. The tropin reactions of meningococei are specific, dividing them into welldefined groups, with no cross-reaction between the typical strains of the main groups. Sisty-tlurec strains of meningococei were available for classification according to their tropin reactions. They werc divided into four distinct groups, designated R, S, T, and U. Group R included 61.9 per ${ }^{\circ}$ ent. of the strains; group $S$ incluted 25.4 per cent. of the strains; group ' $T$ included 4.7 per cent. of the strains and group $U$ included 1.6 per eent. of the strains. Groups $R, S, T$, and $U$ are distinet groups. Every strain belonging to those groups was equal to every other strain of the liomologous group in its power of absorbing tropins from serums of the homologous group. The typical strains of groups $\mathrm{R}, \mathrm{S}, \mathrm{T}$, and U did not absorb tropins specific to a licterologous group. But 4 atypical strains were found which did, in a slight degree, albsorb tropins of another group. A fifth gronp (Z) included 6.4 per eent. of the total number of strains of meningococei. Unlike the other four groups, group $\mathrm{Z}$ is not distinet but is related to the others. This relationship is shown by a partial absorption of tropins spccific for those groups. Morcover, the strains of group $\%$ differ in their relationship to one another, and they differ in their relationship to the four inain groups The strains of group $Z$ are further distinguished by a tendency to spontancous phagocytosis. In the majority of inımıne scrums a good tropin content is accompanied by a good agglutinin content. But agglutinins may be produced without tropins, and tropins may be produced without agghlutinins. Under unfavorable conditions the deterioration of agghtinins and tropins did not follow a parallel course. Certain conditions destroyed the action of the agglutinins witlout injuring the tropins, 